\title{
Hybrid
}

Revue des arts et médiations humaines

\section{From Author to Data Processor in Postdramatic Theatre: Crash Testing the Classics?}

Annie Dorsen's algorithmic Hamlet-adaptation

\section{Claire Swyzen}

\section{(2) OpenEdition}

\section{Journals}

Electronic version

URL: https://journals.openedition.org/hybrid/1372

DOI: 10.4000 /hybrid. 1372

ISSN: 2276-3538

This article is a translation of:

De l'auteur à l'auteur-machine dans le théâtre postdramatique : les classiques soumis au crash test ? URL : https://journals.openedition.org/hybrid/1374 [fr]

\section{Publisher}

Presses universitaires de Vincennes

\section{Electronic reference}

Claire Swyzen, "From Author to Data Processor in Postdramatic Theatre: Crash Testing the Classics? ", Hybrid [Online], 5 | 2018, Online since 01 April 2019, connection on 12 April 2022. URL: http:// journals.openedition.org/hybrid/1372 ; DOI: https://doi.org/10.4000/hybrid.1372

This text was automatically generated on 12 April 2022.

Revue Hybrid 


\title{
From Author to Data Processor in Postdramatic Theatre: Crash Testing the Classics?
}

Annie Dorsen's algorithmic Hamlet-adaptation

\author{
Claire Swyzen
}

\section{AUTHOR'S NOTE}

Note: The research conducted for this article is part of the Interuniversity Attraction Poles Program financed by the Belgian government (BELSPO IAP VII/01).

"Shakespeare...is no longer just textual or theatrical in any conventional sense of the

terms."

(Daniel Fischlin) ${ }^{1}$

\section{Prologue: of an "Unoriginal Genius"2}

For many, Shakespeare is still an unchanging "contemporary" of ours, as Jan Kott and Boleslaw Taborski phrased it back in the 1960s. ${ }^{3}$ From this perspective Shakespeare's work tends to be treated as a bible-hence his status of bard, a term kin to prophet. For Belgian playwright Paul Pourveur Shakespeare is dead, get over it! (2003) and no longer has something to tell us in our $21^{\text {st }}$ century world. With this title for a play Pourveur declares Shakespeare a dead playwright, but also declares dramatic theatre dead as a "model [that] [...] no longer express[es] [...] the postmodern worldview." ${ }^{4}$ With more nuance, John Drakakis suggests that not the work of Shakespeare itself, but its use can signal the postmodern: "With the endless circulation of Shakespeare quotations now sharing the same status as other forms of representation, we have entered the realm of the postmodern." ${ }^{5}$ Pourveur's provocative anti-tradition statement "Everything 
preceding Heiner Müller belongs in the museum" nevertheless confirms an established idea that the postdramatic canon starts with Heiner Müller, author of the paradigm shifting theatre text Die Hamletmaschine (1977). ${ }^{6}$ As dramaturge Erwin Jans pertinently put it: "who or what is actually dead if Shakespeare is dead [...]?"7

Long after Peter Szondi's announcement of the "crisis of drama" in Theorie des modernen Drama's (1956), and in the trail of Barthes's declaration of "The Death of the Author" (1967) followed, in the theatre, several deaths: The Death of the Playwright? (Page 1992), The Death of Character (Fuchs 1996) and even, implicitly, "The Death of the Text"-at least according to a not unpopular interpretation of Hans-Thies Lehmann's concept of Postdramatic Theatre (2006) as visual, post-text theatre. This reduction makes abstraction of the specificity of the dramatic model: the dominance of its logos over the other theatrical 'languages' of performance (sound, movement, embodiment...), imposing a teleological narrative of a moral conflict to be overcome. ${ }^{8}$ Die Hamletmaschine shatters this logos attributed to human reason, along with its language. In the postdramatic paradigm, the "literal" death of Shakespeare seems far less interesting to stage than his metaphoric death. ${ }^{9}$ By the latter, avant-garde directorauteurs position themselves vis-à-vis theatre tradition, its canon and/or the auctorial model of the genius. "Maybe I wanted to kill Hamlet," confessed Annie Dorsen, educated in directing at what she experienced as the fairly conventional Yale School of Drama, and director of the data-processing Hamlet adaptation A Piece of Work (2013), that I will discuss. ${ }^{10}$

However, with Mark Fortier I tend to argue that programmatically killing Shakespeare on stage also means putting him in the spotlight and creating what Daniel Fischlin calls "the Shakespeare effect," a "function of Shakespeare's cultural pervasiveness, in which echoes, resonances, and direct integration of that effect are in evidence in a given play." "11 So, if Shakespeare is revived by killing him, in what form, then, may the killed author rise from the dead?

With the "author as data processor" I label a specific contemporary auctorial model by referring to the $20^{\text {th }}$ century technology of digital information processing, not to state that this intermedial approach of writing as the adaptation and appropriation of text data is new, but to historicize it. We seem to witness-(since about half a century?) the reemergence of a tendency towards less author-centered conceptions of writing reminding of, but of course not identical to, conceptions of the past. In Shakespeare's time, the concept of individual authorship was only on the verge of being established: our "bard" was, in practice, an actor furnishing the theatre with text, in collaboration with other actors, appropriating circulating texts, plots and themes. ${ }^{12}$ Even what is deemed the play of all plays "is certainly not "original," as Shakespeare drew on an extant Ur-Hamlet..$^{13}$ Nevertheless, Shakespeare's adaptation of the Ur-Hamlet is considered an "original" text. Such a view illustrates two of the "Twelve Fallacies in Contemporary Adaptation Theory" pointed out by Thomas Leitch: "Source texts are more original than adaptations" and "Adaptations are intertexts, their precursor texts simply texts." ${ }^{14}$ Ironically, by the distributive power of print culture and through the retrospective lens of Romantic and individual authorship, Shakespeare the adapter and in a way data processor avant-la-lettre "became, after his death, the very model of the universal genius. ${ }^{15}$ 


\section{"moving information"}

5 In Unoriginal Genius (2010) Marjorie Perloff states that writing in the 21st century has become less a question of inventing than of repurposing text. Some go even as far as to claim that in the 2010s "the mash-up rule[s]" and "becomes a trope for intermediality in the digital age." ${ }^{16}$ Or in the highly citable words of Perloff's follower Kenneth Goldsmith: "I used to be an artist, then I became a poet; then a writer. Now when asked, I simply refer to myself as a word processor." ${ }^{17}$ The next model we may expect him to proclaim is that of the coder (from the artist to the nerd...). This does not keep Goldsmith from predicting, like a bard, that authorship today tends to shift towards what I would more generally call a "data processor" on a continuum ranging from "strong" auctorial models like the romantic conception of the genius to "weak" models like those of oral traditions, collaborative (digital) writing, appropriation and so-called Uncreative Writing. ${ }^{18}$

6 The author as data processor foregrounds the act and the material of writing as the processing of text data, facilitated in western "linked computer culture" by data's hyper-availability, potentially cut-and-paste-able, and 'mashable' in no time. ${ }^{19}$ Perloff calls this literary practice "moving information," paraphrased by Goldsmith as "the act of pushing language around as well as the act of being emotionally moved by that process." 20

7 The term is especially appropriate for theatre, as the performance space adds a third sense to it: text data are not only being moved by authors (mobile), and are not only moving audiences (emotional), but are literally in motion on stage. In what follows, I will first discuss three aspects of "moving information" that are strongly related to the model of the author as data processor and to the text data used:

$81^{\text {st }}$, a technological one, the transcodability and "discretization" of text data;

$9 \quad 2^{\text {nd }}$, a compositional one, their "citationality"; and

$103^{\text {rd }}$, a performative one, their kinesis.

11 Then, I will discuss Annie Dorsen's algorithmic Hamlet adaptation A Piece of Work from this threefold perspective.

\section{Transcodability}

12 Technically, "moving information" is what makes new (= digital) media "new". Digital computing has in certain ways increased the mobility of information; it can be "transcoded" from one digital format, "platform" or medium to another and vice versa, seemingly as easy as a magic trick: ${ }^{21}$

text typed into a Microsoft Word document can be parsed into a database, visually morphed in Photoshop, animated in Flash, pumped into online text-mangling engines, spammed to thousands of e-mail addresses, and imported into a sound editing program and spit out as music. ${ }^{22}$

13 Transcoding is only possible because "data" are the result of a process of breaking information up into small and uniform units, an ongoing cultural and historical process which Bernard Stiegler calls "discretization." ${ }^{23}$ Discretizing or sampling analog information means "turn[ing] continuous data into discrete data [...]," "the process whereby the currents and continuities shaping our lives become discrete elements," for 
instance "[w]riting, as the breaking into discrete elements of the flux of speech [...]." ${ }^{24}$ Digital information is per definition discretized, it consists of uniform units in binary code, or simply, "data." For the first time, it seems, a writing tool simultaneously functions as a provider of information that invites to manipulate that same information: the computer converges the functions of data storage, processing and production. ${ }^{25}$ The Internet as a huge cultural digital database of information is technologically integrated into the writing process. ${ }^{26}$ Perhaps more than "the text," as Barthes has it, the computer, or better, the author as data processor is, "a multidimensional space in which a variety of writings, none of them original, blend and clash." ${ }^{27}$ It is the digital nature of data, in the sense of discrete standardized units in binary code, that enables authors and auteurs as data processors to easily move information. Linda Hutcheon and Siobhan O'Flynn define the practice of adaptation in terms of "a transcoding process." ${ }^{28}$ Transcoding, here, can be a metaphorical act as well as a technological reality.

In Facebook Theatre (2015) Ivo Dimchev has an offstage dramaturge rewrite the audience's real-time Facebook comments about the performance into dialogues, which then serve as the input for the performers via earpieces-whose output is again commented on, and so on, in a text-to-text transcoding loop. ${ }^{29}$ In cyber artist Stelarc's groundbreaking 1990s telematic performance Ping Body: An Internet Actuated and Uploaded Performance (1996) abstract "movement" or activity on the Internet (e.g., textual input by users) is transcoded by means of a muscle stimulator into Stelarc's own physical movement onstage. ${ }^{30}$ What these kinds of performances explore is how far technology's capacities can push the limits of human capacities of data processing (of language data and ideas for the performance; of physical stimuli).

\section{Citationality}

Having databases at hand is not a condition for adaptation and appropriation practices. Historically, writing seems always to have been a form of (intertextual) rewriting - "there is nothing beyond adaptation" and in this sense even the most provocative adaptation is "not innovation but renovation." "31 Yet, a poetics of "citationality," as Perloff recycles Antoine Compagnon's idea of "récriture," indeed seems "the logical form of "writing" in the age of literally mobile or transferable text." ${ }^{32}$ What digital culture radically facilitates is the recombination of data due to their connecting potential. Discretized, data are open to potential new connections (with other data and/or other contexts). This echoes dramaturgical practices that connect material from various sources into new semantic and aesthetic contexts. But whether "reproducing, assembling, and hijacking pre-existing" discourses and, I would add, canons, is used for contestation or confirmation, citing's "erasure of context from individual quotations, or from those works as a whole that we designate "literary," is an irreducibly ideological operation," the more so in the case of canonical œuvres like Shakespeare's. ${ }^{33}$ Legitimizing citation practices tend to fetishize canonical works, either by citing them literally, or by referring to them in crafted "Shakesthings," as Sujata Iyengar calls goods of relatively low material value that have been "upcycled" by means of Shakespeare's "cultural capital." ${ }^{34}$ Conversely, citing practices that resist the temptation of coherence and essence stand for "the idea of Shakespearean texts as sites of contestation, as opposed to being repositories of cultural wisdom." ${ }^{35}$ 
16 A question to ask, then, is: What kind of language do authors/auteurs "move," from where, why and how? In their dérive, authors as data processors wander more virtually than physically, hoarding text objects in all possible digital genres and formats, delighted at what they find. (They find, among others, digitalized Shakespeares.)

When toddlers play with toys, what they do is test whether they can break the toy into pieces. Slightly older, they make new constructions with whatever object they find suitable, disregarding its initial purpose. Citational poetics, I imagine, is that kind of crash-testing of cultural objects and then repurposing them-especially when they are claimed to be unbreakable, like Shakespeare.

\title{
Kinesis
}

The text in postdramatic theatre has not left the stage, as is so often proclaimed, but its modes of production, its functions and appearances have changed. In theory and in practice, the performative aspect of writing and of language in the theatre is increasingly highlighted. Inspired by Joseph Roach's idea "that kinesis has become more important than mimesis in contemporary performance," Matt Cornish distinguishes two kinds of theatre texts: playtexts and what he calls "kinetic texts,"

\begin{abstract}
themselves objects in motion: they possess kinetic energy, living through performance. As printed, or just handwritten or saved as Microsoft Word documents, these texts neither represent performance nor encourage representation in theatrical presentations. The worlds they present are not whole. [...] Often created through performance, kinetic texts exist between forms and categories, read first as rules for improvisation and more closely as literature, then for the sounds of the words, reverberating objects drained of symbolism; and then again for their instrumentality. ${ }^{36}$
\end{abstract}

Jerome Fletcher starts from a similar observation, but concerning digital text, that the changed function and appearance of text requires a new way to conceive and perceive text in performance:

Typically, digital text is projected into this space and accompanied by the human body in performance, either in response to or in opposition to the text projection. [...] However, [this performative dimension is] still thought of as a postlude or a supplement to the process of writing that has already taken place. [...] Performance comes after writing. ${ }^{37}$

This is even more the case for stagings of digital Shakespeare texts, as the relation between Shakespearean text and performance is mostly asymmetrically conceived, considering "the written text as the repository of authorial truth." ${ }^{38}$ Fletcher, then, proposes that "[r]ather than seeing [writing] as the end-point, the outcome of the digital device or apparatus, we can consider the question of how writing performs throughout the entire apparatus/device," by which he seems to mean dispositif. ${ }^{39}$ Would it, however, not be as relevant to inverse Fletcher's question: how does the digital apparatus perform through writing for and in the performance space?

Apart from the observations by Cornish, Fletcher, Lehmann and others, that the text has been symbolically displaced in postdramatic theatre, and that the Shakespeare text is being "increasingly decentered" in adaptations across genres and media, what does the more literal kinesis of such texts look like? ${ }^{40}$ Text data are literally moved around in the form of cards or printed playtexts, text appears and disappears, is scrolled, is projected on all kinds of 'screens', including bodies, deforming words. The kinesis of 
text data applies to analog and digital texts alike, in low-tech as well as high-tech performances, staging the real-time generation of texts in natural languages or in code. But also in a dramaturgical sense language is being moved around in the theatrical time-space. Either machine language (code) or natural language is written word for word and edited in real time. Alternatively, text is hypertextually composed by combining already available, text blocks or "lexia."

Fig. 1

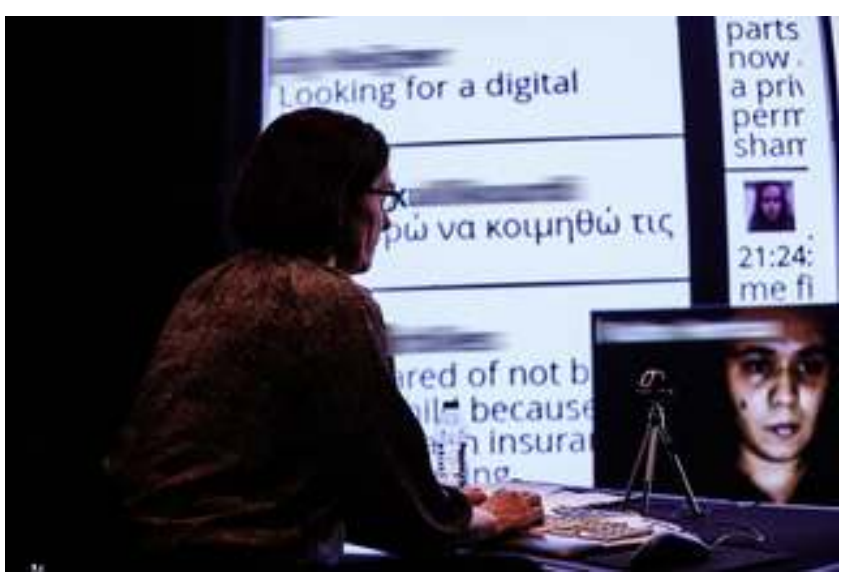

Edit Kaldor on stage behind her computer in Web of Trust. This picture was taken during the performance in Greece but has the same set-up as the Spring version in Brussels of May 2016 (the names of the people chatting have been disclosed for privacy reasons).

(c) Cristos Sarris for Onassis Cultural Centre Athens.

In his self-declared "Poor Techno-theatre" Porto Rican Aravind Enrique Adyanthaya stages what he calls "act-writing," acting in the form of writing. ${ }^{41}$ Edit Kaldor, in her social media performance Web of Trust (2016), invites logged-in participants present in the theatre or online to write and edit the performance's and social network site's working principles..$^{42}$ Live Coding practices in general approach "programming as performance art, performance art notation as code" and are interested in performance as the "revelation of digital code." ${ }^{43}$ In all of these and similar cases, text is projected on a screen while being written in the theatrical space, so the text's and technology's performativities converge. The "cursor" becomes "the location of action and retraction, of cut and paste, of deletion and erasure, insertion and manipulation." ${ }^{44}$ The text's live composition, here, is a performance in itself. ${ }^{45}$

\section{"Algorithmic theatre" and canonical data}

Distinguishing her work from what she considers "multimedia performance," with her digital "algorithmic theater" Annie Dorsen aims to "investigat[e] [...] the dramaturgy of algorithms themselves, which is to say their way of ordering the world, the particular kinds of meanings they make, the kinds of narrative structures they imply." ${ }^{46}$ Algorithmic theatre, however, need not be "digital" in the common meaning of "related to computers." In general terms, "[a]n algorithm is an effective procedure, a way of getting something done in a finite number of discrete steps. [...] an algorithm, speaking loosely, is a set of rules, a recipe, a prescription for action, a guide [...] ${ }^{{ }^{47}}$ As a dramaturge in collaboration with director Lucas Vandervost I worked on what was, in 
retrospect, an analogue algorithmic performance using an artisanal Shakespearedatabase. ${ }^{48}$ What You Will. Something by Shakespeare (2007) [Elk wat wils. Iets van Shakespeare] of the Belgian theatre company De Tijd was a far from "techy" looking, dedramatized collage of words and phrases from the whole dramatic œuvre of the Bard, metaphorically "passed through the paper shredder" (though we started by using scissors and ended up using a computer).

Building on his previous lo-fi algorithmic performances, Orion Maxted's recent work [THE BRAIN] approaches the audience collectively as "a giant brain that is capable to thinking, solving problems and making a performance." ${ }^{49}$ Algorithms enable human authors to delegate authorship to human or software-run performers by providing instructions.$^{50}$ In Dorsen's earlier Hello Hi There (2010), the algorithms designed for the two chatbot-performers made them produce dialogue. Dorsen has a point, then, when she considers the "writing of algorithms [...] creative work, as there are always multiple ways of solving any particular problem," but also the writing by the algorithms. ${ }^{51}$ The ones developed for her Hamlet-adaptation A Piece of Work (2013) "were designed to act as artistic partners: co-writers, co-directors, co-designers, and performers" on stage to "autonomously create and perform an adaptation of Shakespeare's play according to algorithmic principles." ${ }^{52}$ The algorithms "are simple-they skip, sort, replace, and sequence" words of Hamlet. ${ }^{53}$

Dorsen could have chosen less mythical canonical data to work with, like in the yearly "Death of the Authors" project of media art association Constant, based in Brussels, the same city where the Kaaitheater hosted several of Annie Dorsen's shows. Treating literary texts of which the rights have expired as databases, Constant's algorithms produced "generative novels" and a "bot opera," featuring chatbots behaving differently with data and interacting with printers, projected images and the audience. ${ }^{54}$ But treating Hamlet as a text database is a choice implying more than just a desire for textual experimentation and technological insight. Considering A Piece of Work "a literal 'hamletmachine' [...] [Dorsen] chose Hamlet because of its status as the canonical humanist theater text. Harold Bloom, an emblematic spokesperson for this view, names Hamlet the play that invents what we humans understand ourselves to be." For Dorsen, the claim about Hamlet's "consciousness of his own consciousness," as Bloom puts it, "made the play the obvious choice to explore how algorithms might change the way theater constructs representations of the human." ${ }^{55}$ Accordingly, she reduced the play of all plays to data "that the computer can understand," to say it with Katherine Hayles. ${ }^{56}$ The emphasis Dorsen puts on Hamlet would almost make one forget another fallacy from Leitch's list: "Adaptations are adapting exactly one text apiece." ${ }^{77}$ For sure, Dorsen is adapting Shakespeare's Hamlet, but also Heiner Müller's Hamletmachine and, in quantity perhaps as important as these literary precursors are the computer code and software models that Dorsen and her team adapt in order to have a machine generate versions of Hamlet.

How then, did Dorsen and her team break Hamlet up into small pieces and make this Shakespeare-data apt for citation? According to what principles is it recombined and theatricalized? Is this practice of live writing with machines rendered visible and kinetic during the performance? Where does the 'writing' take place and by whom-or what?

As Annie Dorsen has already explained and reflected on mainly the software and technical aspects of A Piece of Work in her introduction to the book publication of the 
text, and Iona Jucan's article looks deeper into the logic of algorithms, I will focus more on what is relevant for the idea of the author or performer as a data processor and on the related aspects of discretization, citationality and kinesis. ${ }^{58}$ The way the text is produced, the way it appears in the performance and the way it functions will be central to the discussion.

\section{An Aside: A Laptop View of a Live Performance by Digital Algorithms}

Published interviews, private talks with Annie Dorsen as well as her Introduction to A Piece of Work in Emergency Playscript's publication of the play text provided me with information concerning the production of the text. For my analysis of the text's effect and function in the performance, I rely on a video recording of the performance at the Brooklyn Academy of Music in December 2013, where it ended its tour, after having travelled to Seattle, Oslo, Bergen, Vienna, Rotterdam and Paris that same year. ${ }^{59}$ Even though I have not seen the performance live, I have seen it, partially-after all, "what [does] it [mean] to 'see' work in the context of telematic performance and digital media"? ${ }^{60}$ Sarah Bay-Cheng raises the question in her article "UNSEEN Performance Criticism and Digital Recordings," in which she convincingly argues that not only the experience of the performance's document (e.g., a video recording) is incomplete, but also "the experience of copresence is not itself a complete version" of a performance. ${ }^{61}$ What Bay-Cheng proposes, then, is not to take video recordings of performances at face value, but "to look with a perspective learned from reality television, where the viewer questions both the accuracy of the media representation and the reality on which the documentation is based, while simultaneously attending to the affective relations developed by the screen versions." ${ }^{62}$ In that respect, I am lucky that A Piece of Work was recorded with a fixed camera, mainly from a central point of view, showing about five rows of audience members sitting below the camera. When other camera angles are adopted (e.g., from aside, when the "ghost" is speaking), it is still able to locate the place of the camera, even in the case of the few close ups on the human performer (on the evening of the recording this was Scott Shepherd, not Joan MacIntosh). Technically, there is quasi no difference whether the synthetic voices, the text and the algorithms running the lighting and sound effects are generated by a computer in the theatre or by my laptop-both can be considered "machines for generating affect," in the words of Steven Shaviro. ${ }^{63}$ This is especially the case here, because the textual and sensory data generated by Dorsen's algorithms could be exactly reproduced (if Dorsen wanted to), contrary to a performance that mainly relies on biological or ecological agents (humans, animals, the weather). However, I am well aware that the presence-effect even of non-human agents like the algorithm-driven lighting, sound-effects and projected text cannot be denied..$^{64}$ I therefore also count on my twelve years of experience as a dramaturge, observing the differences between rehearsals, try-outs, premieres and 'days after' as well as between performances and their recording('s camera angles and close-ups), photographs, reviews and audience accounts. All these factors help me in trying to imagine what the "live" experience of the performance in the theatre, being copresent with the audience, of performing algorithms in combination with one human actor, could have been like, without claiming that I know what they were like as if I had been there. 


\section{“Human-machine collaboration"}

Dorsen's endeavor would probably have been impossible as a solitary author, due to a lack of time and financial means if she had not been able to rely on an already discretized digital version of Hamlet. This was made available by the academic WordHoard project, which turns canonical texts into databases of tagged linguistic "data." ${ }^{5}$ Since tagging is distinguishing items from other items (e.g., words, grammatical constructions) it also means isolating and hence discretizing them.

Dorsen and programmer (and media theorist) Mark Hansen used WordHoard's digital and tagged Hamlet-data but developed their own algorithms to generate text from this database. They relied on the algorithmic principle "Markov chain," a model to process data that generates combinations and variants whose occurrence is probable according to the characteristics of the data (e.g., recurrent grammatical patterns). Typical of Markov chains is that the process of generating text is "memoryless": when the algorithm produces sentences by recombining data, this is disconnected from previously produced text data. ${ }^{66}$ Hence, the recombined text data's eventual coherence is not due to intelligence as understanding but as the mimicking of "the statistical order of the words in the original text" (and the audience's expectations). ${ }^{67}$

31 To increase coherence, Dorsen and her team added "a small set of simple semantic and theatrical rules to impose on the generated text," for instance "a character may only speak after entering, or should not say his/her own name". ${ }^{68}$ In doing so, she reintroduced-though in a minimalist way-the kind of realist theatrical conventions that she intended to question in the first place. An additional constraint imposed by Dorsen was to limit a given task to only specific, quantifiable parts of the play (e.g., a famous scene, a specific number of lines etc.) Finally, Dorsen and her team built in what can be considered as yet another interpretative filter by tagging each word of the play with what they called "emotion scores": "We broke our data down in several different ways to allow for a variety of uses." ${ }^{69}$ These tagged data served as transcodable input for the sound, music, video and lighting systems of Dorsen's hamletmachine or "autonomous theatrical intelligence". ${ }^{70}$

32 Espen Aarseth, in Cybertext (1997), considers three basic relations in "human-machine collaboration" when it comes to the production of (literary) text: "(1) preprocessing, in which the machine is programmed, configured, and loaded by the human; (2) coprocessing, in which the machine and the human produce text in tandem; and (3) postprocessing, in which the human selects some of the machine's effusions and excludes others." ${ }^{11}$ Hence, "The key question in cyborg aesthetics is therefore, who or what controls the text?"72 Dorsen acknowledges the coauthorship of programmers Dylan Fried and Mark Hansen (and performer Scott Shepherd, who did additional programming in a later phase) as well as that of the algorithms-without erasing herself from the picture: “[ $t]_{0}$ the extent that this adaptation of Hamlet was 'written' by me, it was these so-called configurations files that I wrote" (i.e., part of the preprocessing)..$^{73}$ 


\section{"Atomization of language"}

33 In the end, Dorsen and her programming team developed five different algorithms to generate 'new' text from the Shakespeare-data in real time, mimicking the five-act structure of the play. The subtitles Dorsen gave to the acts loosely indicate what each specific algorithm does. ${ }^{74}$ (I will only discuss the algorithm's main tasks here.) In "Act 1: SCENE" the algorithm mainly skips: it reproduces the first $4 \%$ of every scene, scene by scene, with the effect, more or less, of an abridged version. "Act 2: LINE" relies on keyword detection and sorting: the algorithm selects lines from the entire play that start with a specific keyword ("what," "I" or "O"), and reproduces the lines according to their length, from the longest to the shortest. This has a poetic effect of rhyme, repetition and, as the lines get shorter, disintegration. In "Act 3: GRAMMAR" the available data is limited to the soliloquies, in which the algorithm first identifies words according to their grammatical categories (e.g., nouns) and grammatical structures. Then, it generates new soliloquies by replacing original words of the play by other words of the play pertaining to the same grammatical category, and according to the common grammatical structures in Hamlet. This act is played by a human performer, either Scott Shepherd or Joan MacIntosh, whose relations to the Wooster Group inevitably evoke Liz LeCompte's contrary citational version of the same classic text, or better, of the "theatrofilm" filmic record of the classic's staging. ${ }^{75}$ (Shepherd and MacIntosh's use of earpieces in A Piece of Work also recalls LeCompte's systematic transmission of data to the performers through earpieces during performances.) For those who know the soliloquies, the replacement of words by the algorithm draws attention to the potential and factual variety in (the Folio and Quarto versions of) Shakespeare's text. Acts 4 and 5, then, use Markov chaining: the algorithm produces variants on the original by mimicking it, i.e., reproducing statistically probable combinations of letters, words, grammatical structures etc. Act 4: WORD" "generate[s] new scenes by re-sequencing words" and "Act 5: LETTER" "generate[s] a new final scene $[. .$.$] by resequencing letters" from the original Act 5, Scene 2$ of Hamlet. ${ }^{76}$

The five subtitles of the acts indicate an increasing "atomization of language," dramaturgically corresponding to the character's falling into pieces and coinciding with the audience's experience of speech either falling apart or becoming hardly recognizable. ${ }^{77}$ Furthermore, the gradual movement from Act 2's keyword repetition to the replacement of words by words of the same category in Act 4 and the recombination of letters in Act 5, corresponds to a shift identified by Lev Manovich as a manifestation of "computer culture": the relative retreating of syntagmatic (storytelling) modes to the background of culture, and of paradigmatic modes of composing or meaning making to the foreground. ${ }^{78}$ Paradigms underpin the logic of "database forms" (or older cultural forms like the encyclopedia) and facilitate citationality. ${ }^{79}$ Especially A Piece of Work's Act 3: GRAMMAR shows paradigmatic writing at work, orally mediated by a human performer:

to be, and not to be: all Is a colour:

to be, and not To be: those is a exercise:

to be, or not to be: some is a man:

to be, And not to be: all Is the fortune:

Whether 'tis nobler by the pause to say

To be, and not to be: all is The precurse:

while 'tis stronger in a name to put 
the nations and uses of poor appointment,

and To keep eyes at the life of bodies ${ }^{80}$ coauthorship? As Iona Jucan remarks, algorithms are normally designed to make big data "intelligible" to humans, whereas the algorithms of Dorsen and her team make a small database of understandable Shakespeare relatively "unintelligible." 81 A Piece of Work "disarticulate[s]," the text of a highly articulate and canonical character, for a long time considered the essence of humanism. ${ }^{82}$ In the meantime, there is more or less of a consensus in Shakespeare and literary scholarship about the impossibility of attributing any final meanings to the text, revealed as the product of multiple versions and borrowings by Shakespeare. Yet, outside this circle of specialists, the idea still seems to dominate that Hamlet is a human character and condition rather than a text.

Fig. 2.

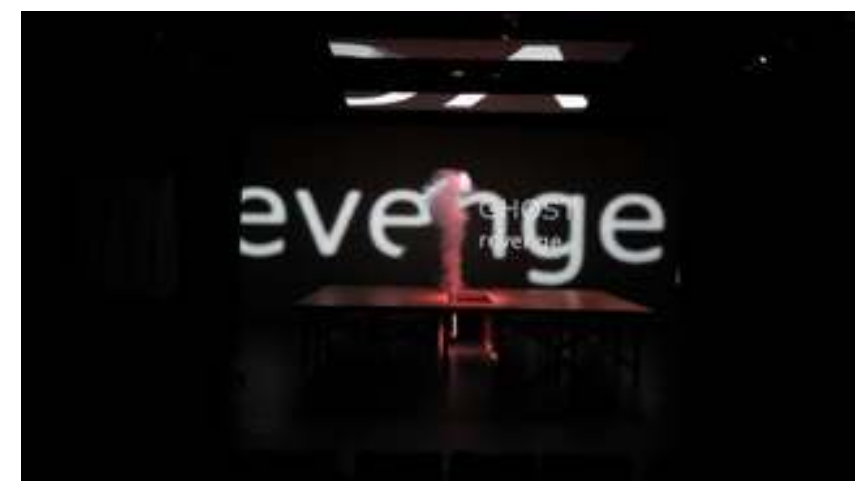

Annie Dorsen, A Piece of Work (2013) : "autonomous theatrical intelligence." (c) Bruno Pocheron.

Stagings like Annie Dorsen's refocus attention towards canonical works as texts in the first place, to such an extent that Thomas Cartelli speaks of A Piece of Work in terms of "the production's textual monopoly." ${ }^{83}$ Dorsen's performance turns Hamlet into what Katherine N. Hayles calls a "technotext," not because it looks digital, but because it puts the materiality of language in the spotlights, "interrogates the inscription technology that produces it" and "mobilizes reflexive loops between its imaginative world and the material apparatus embodying that creation as a physical presence." 84 This echoes the self-reflexive tendency of postdramatic theatre to foreground its medium specificity and processual character. ${ }^{85}$

Projecting text onto a screen is the most common way in which postdramatic theatre and performance turn text into an object. ${ }^{86}$ The projected text data from Shakespeare's playtext in A Piece of Work, including stage directions, are generated in real time and transcoded into other media: synthetic computer voices, video, lighting, music, a fog 
machine. Metaphorically, what Dorsen herself calls "text-as-data" are also transcoded into the human voice of the performer (either Scott Shepherd or Joan MacIntosh, depending on the evening) by means of an earpiece, a human brain and a speech organ. ${ }^{87}$ For example, text data like the word "ghost" set in motion a fog machine, spotlights that illuminate the fog and lend the ghost a specific voice and oversized font that semantically emphasizes absence all over. Dorsen exposes the theatrical apparatus as a machine that produces an effect of presence by means of human, but mainly nonhuman, mechanical, but mainly digital technologies as performers. With the projected code that begins and ends the performance and structures it in between Dorsen indicates the meta-level of the theatre as a machine.

Fig. 3

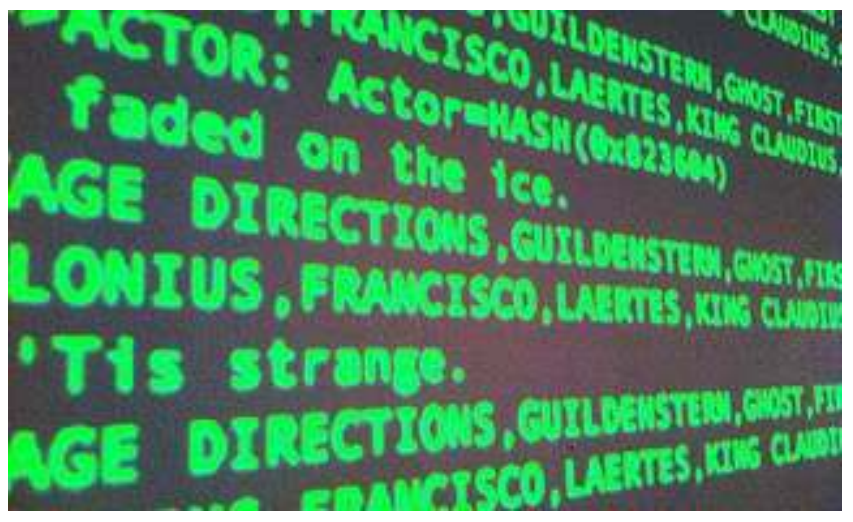

Annie Dorsen, A Piece of Work (2013) : code.

(C) Annie Dorsen.

But Dorsen also deploys: an isolated theatre curtain (now and then moved by a wind machine); spotlights; a stage with a rectangular hole in it, suggesting a prompter's box (the algorithms as prompters?) or a trap for disappearance tricks (exit human consciousness?)-all stock elements of $19^{\text {th }}$ and $20^{\text {th }}$ century dramatic theatre. Dramatic and postdramatic elements, even in digital performance, coexist in the "continuum" between drama and postdrama. ${ }^{88}$ To create this automatically generated theatre and this kinetic effect, Dorsen's hamletmachine seems to have internalized (Dorsen and co. have programmed it to apply) some conventions of dramatic theatre. These increase the probability that most of its output will be relatively intelligible for humans acquainted with those conventions. As certain words are emotionally coded (i.e., culturally) and transcoded into voices, lighting etc. in a manner that tends to illustrate the text, at bottom, in a realist tradition (e.g., Polonius gets the voice of an old man, etc.), a minor degree of psychologizing characteristic of $19^{\text {th }}$ and $20^{\text {th }}$ century dramatic theatre reenters the stage where it was meant, dramaturgically, to exit by means of citationality. Unavoidably, Shakespeare's lines not only perform as language, but, similar to Gerardjan Rijnders's and Guy Cassiers's performance with projected text, Rotjoch (1998), the lines attributed by the author to characters on the page again perform as characters on stage: due to the quality of their voice, the soundscape (e.g., trumpets) accompanying them and the typography of their projected words. Of course, also the anthropomorphizing tendency of the audience plays a role here. The words even seem to acquire an auratic presence despite their ghostly, "screenic" being. ${ }^{89}$ Yet, compared to her algorithmic performance Hello Hi There (2010), heavily constrained by 
the dramatic convention of dialogue, in A Piece of Work Dorsen seems to have much further explored "the computer's potential for combination and world simulation in order to develop new genres that can be valued and used on their own terms [... and to] focus on the computer as literary instrument: a machine for cybertext." ${ }^{10}$ How much further could she have gone?

\section{Just how hard should a crash test be?}

Contrary to Drakakis's insight that "Shakespeare now is primarily a collage of familiar quotations" the dramaturgical approach of Dorsen more often than not defamiliarizes citations by reconnecting them with other data..$^{91}$ Does citationality then still have the effect of citationality when citations are difficult to identify? Perhaps it suffices to know that we hear quotes from $\mathrm{X}$ without being able to identify them, so Hamlet still stays "an always already known commodity"-the commodification of Shakespeare being the object also of Pourveur's previously mentioned play. ${ }^{92}$ Perhaps, in the era of big data, performances like A Piece of Work ask for another attitude of the audience towards text in the theatre: being prepared to experience language patterns (visually and aurally) instead of wanting to rationally understand word by word. Human or nonhuman, managing the risk of citational and recombinant aesthetics apparently means limiting the random aspect of algorithmic performances and settling for some sort of randomness that has to take into account not only technological, but also human limits.

Crash testing a classic like Hamlet, then, is not simply an act of crashing it against the wall in contestation, but rather a difficult exercise in precisely estimating how hard the crash may be in order to safeguard what is crashed. Safeguarding here means: keeping it sufficiently recognizable in its brokenness, its state of being data processed. The more the cultural object goes "in pieces," to cite Andy Lavender, the more it risks no longer to be recognized..$^{93}$ And when it is no longer identifiable, then neither is the performance of the crash test as a form of cultural-technological provocation. This is perhaps the new craft of authors and auteurs as data processors: calculating the probability that the chosen object will come out of the crash sufficiently broken, but still identifiable enough.

\section{Epilogue: of the Performer as Human Data Processor}

What, exactly, is being tested in Dorsen's A Piece of Work? Is it only the limit where Hamlet ceases to be Shakespeare's Hamlet as we know it? Or also the point where the human performer no longer functions as the seat of human consciousness? A Piece of Work's Act 3 (temporally situated in the second quarter of the performance) starts with Scott Shepherd sitting on the first row, facing the stage, reading and speaking out loud the words that appear on the projection screen. However, the pace of the projection speeds up in such a way that it no longer seems possible that the performer's speech is a consequence of his reading. But unless Dorsen's announcement that the chatbots generate text in real time is untrue, then the performer cannot know the words by heart either, because each evening the algorithms generate other (combinations of) words. When in a next section Shepherd turns around his chair and faces the audience, no text is projected. The text is no longer mediated by the interface of the screen, but 
only by the performer, whose voice now orally mediates the words generated by an artificial intelligence.

\section{BIBLIOGRAPHY}

Aarseth, Espen, Cybertext: Perspectives on Ergodic Literature, Baltimore (Md.), Johns Hopkins university press, 1997.

Adyanthaya, Aravind Enrique, “Towards a Poor Techno-Theatre," Performance Research 18, no. 5, October 1, 2013, p. 77-85, [Online] https://doi.org/10.1080/13528165.2013.828926 [accessed 29 March 2019].

Auslander, Philip, “Liveness, Mediatization, and Intermedial Performance," Degrés. Revue de synthèse à orientation sémiologique, no. 101, 2000, p. e1-12.

Barthes, Roland, "The Death of the Author" [1967], in Image Music Text, transl. Stephen Heath, London, Fontana Press, 1977, p. 142-148.

Bay-Cheng, Sarah, “UNSEEN Performance Criticism and Digital Recordings," Theater 46, no. 2 (2016): p. 77-85, [Online] https://doi.org/10.1215/01610775-3550508 [accessed 29 March 2019]. Bennett, Andrew, The Author, London, Routledge, "New Critical Idiom," 2005.

Berlinski, David, The Advent of the Algorithm: The 300-Year Journey from an Idea to the Computer, San Diego, Harcourt, 2001.

Callens, Johan, “The Wooster Group's Hamlet, According to the True, Original Copies," Theatre Journal 61, no. 4, December 2009, p. 539-561.

Cartelli, Thomas, “Essentializing Shakespeare in the Shakespeare Aftermath: Dmitry Krymov's Midsummer Night's Dream (As You Like It), Matías Piñeiro's Viola, and Annie Dorsen's Piece of Work: A Machine-Made Hamlet," Shakespeare Quarterly 67, no. 4 (2016), p. 431-456, [Online] https://doi.org/10.1353/shq.2016.0055 [accessed 29 March 2019].

Cocker, Emma, "Live Notation: - Reflections on a Kairotic Practice," Performance Research 18, no. 5, October 1, 2013, p. 69-76, [Online] https://doi.org/10.1080/13528165.2013.828930 [accessed 29 March 2019].

Constant, "Public Domain Day: The Death of the Author," Constant vzw, [Online] http:// publicdomainday.constantvzw.org/ [accessed 4 March 2018].

Cornish, Matt, "Kinetic Texts: From Performance to Poetry," Modern Drama 58, no. 3, Fall 2015, p. 302-323, [Online] https://doi.org/10.3138/md.0757 [accessed 29 March 2019].

Demoor, Marysa, Ingo Berensmeyer, and Gert Buelens, "RAP - Authorship Studies | Faculty of Arts and Philosophy - Research Portal," [Online] http://research.flw.ugent.be/en/rap [accessed 4 March 2018].

Dorsen, Annie, A Piece of Work, Brooklyn (N.Y.), Ugly Duckling Presse, "Emergency Playscripts 5," 2017. 
Dorsen, Annie, A Piece of Work - with Scott Shepherd, video recording, New York, Brooklyn Academy of Music, 2013. [Online; private video] https://vimeo.com/86944137137 [accessed 4 March 2013].

Dorsen, Annie, “A Piece of Work," [Online] http://www.anniedorsen.com/showproject.php?id=14 [accessed 14 June 2018.]

Dorsen, Annie, "Talk about 'A Piece of Work'. A Group Self-Interview," TDR-the Drama Review 59, no. 4, Winter 2015, p. 133-148, [Online] https://doi.org/10.1162/DRAM_a_00501 [accessed 29 March 201ç].

Drakakis, John, "Shakespeare in Quotations," in Susan Bassnett (ed.), Studying British Cultures. An Introduction, London/New York, Routledge, 1997.

Epstein, Andrew, “Found Poetry, 'Uncreative Writing,' and the Art of Appropriation” in Joe Bray, Alison Gibbons, and Brian McHale (eds.), The Routledge Companion to Experimental Literature, London, Routledge, 2012, p. 310-322.

"FB Theater," Kaaitheater, [Online] https://www.kaaitheater.be/en/agenda/fb-theater [accessed 7 March 2018].

Fischlin, Daniel (ed.), OuterSpeares: Shakespeare, Intermedia, and the Limits of Adaptation, Toronto, University of Toronto Press, 2014.

Fletcher, Jerome, "Introduction," Performance Research 18, no. 5, October 1, 2013, p. 1-3, [Online] https://doi.org/10.1080/13528165.2013.867168 [accessed 29 March 2019].

Fortier, Mark, "Beyond Adaptation," in Daniel Fischlin (ed.), OuterSpeares: Shakespeare, Intermedia, and the Limits of Adaptation, Toronto, University of Toronto Press, 2014, p. 372-386.

Gallop, Jane, The Deaths of the Author Reading and Writing in Time, Durham, Duke university press, 2011.

Geerts, Ronald, "Tekst als object. Over de herwonnen autonomie van de dramatekst," in Claire Swyzen and Kurt Vanhoutte (eds.), Het statuut van de tekst in het postdramatische theater, Brussels, University Press Antwerp/Academic and Scientific Publishers, 2011, p. 105-114.

Gervais, Bertrand, "Is There a Text on This Screen? Reading in an Era of Hypertextuality," in Ray Siemens and Susan Schreibman (eds.), A Companion to Digital Literary Studies, Chichester, WileyBlackwell, 2013, p. 183-202.

Goldsmith, Kenneth, Uncreative Writing: Managing Language in the Digital Age, New York, Columbia University Press, 2011.

Hayles, N. Katherine, How We Think: Digital Media and Contemporary Technogenesis, Chicago/London, The University of Chicago Press, 2012.

Hayles, N. Katherine, Writing Machines, Cambridge (Mass.), MIT press, 2002.

Iyengar, Sujata, “Upcycling Shakespeare: Crafting Cultural Capital," in Daniel Fischlin (ed.), OuterSpeares: Shakespeare, Intermedia, and the Limits of Adaptation, Toronto, University of Toronto Press, 2014, p. 345-371.

Jans, Erwin, "Drama na het drama? Een overzicht van postdramatische theaterteksten in Vlaanderen," in Claire Swyzen and Kurt Vanhoutte (eds.), Het statuut van de tekst in het postdramatische theater, Brussels, University Press Antwerp/Academic and Scientific Publishers, 2011, p. 53-68 
Jucan, Ioana B., "Sys.Begin to Sys.Exit Software Performs A Piece of Work," TDR-the Drama Reviewthe Journal of Performance Studies 59, no. 4, Winter 2015, p. 149-168. [Online] https://doi.org/ 10.1162/DRAM_a_00502 [accessed 29 March 2019].

Kott, Jan, and Boleslaw Taborski, Shakespeare Our Contemporary, Garden City (N.Y.), Doubleday, 1966.

Lavender, Andy, Hamlet in Pieces: Shakespeare Reworked: Peter Brook, Robert Lepage, Robert Wilson, London, Nick Hern Books, 2001.

Lehmann, Hans-Thies, "From Logos to Landscape: Text in Contemporary Dramaturgy," Performance Research 2, no. 1, p. 55-60, [Online] http://dx.doi.org/ 10.1080/13528165.1997.10871532 [accessed 29 March 2019].

Lehmann, Hans-Thies, Postdramatic Theatre, transl. Karen Jürs-Munby, London, Routledge, 2006.

Leitch, Thomas, "Twelve Fallacies in Contemporary Adaptation Theory," Criticism, vol. 45, no. 2, Spring 2003, p. 149-171, [Online] https://doi.org/10.1353/crt.2004.0001 [accessed 29 March 2019]. Manovich, Lev, The Language of New Media, Cambridge (Mass.), MIT Press, 2000.

Maxted, Orion, “Cybernetics vs. Decartes.” Etcetera, [Online] https://e-tcetera.be/cybernetics-vsdecartes/ [accessed 18 December 2018].

"Paul Pourveur over de Jaren 90," Toneelstof-website, [Online] http://toneelstof.be/?

s=Paul_Pourveur_over_de_jaren_90 [accessed 15 June 2018].

Paulos, Eric, “The Human Body as Multimedia,” [Online] http://besser.tsoa.nyu.edu/impact/f96/ Reviews/epaulos/ [accessed 4 May 2017].

Perloff, Marjorie, “Moving Information: On Kenneth Goldsmith's ‘The Weather," Open Letter. A Canadian Journal of Writing and Theory 12, no. 7, 2005, p. 84-95, [Online] http:// writing.upenn.edu/epc/authors/goldsmith/ [accessed 7 March 2018].

Perloff, Marjorie, Unoriginal Genius. Poetry by Other Means in the New Century, Chicago, University of Chicago Press, 2010.

Stiegler, Bernard, "Memory," in W.J.T. Mitchell and Mark B.N. Hansen (eds.), Critical Terms for Media Studies, Chicago, University of Chicago Press, 2010, p. 64-87.

Swyzen, Claire, “Toneelproducties De Tijd: Elk Wat Wils. Iets van Shakespeare,” [Online] http:// www.detijd.be/archief/frames/archief.html [accessed 5 March 2018].

Swyzen, Claire, and Kurt Vanhoutte, Het statuut van de tekst in het postdramatische theater, Brussel, University Press Antwerp/Academic and Scientific Publishers, 2011.

Van den Dries, Luk, “Heiner Müllers ‘Hamletmachine’ in een regie van Jan Decorte (1981): postdramatisch theater avant la lettre," in Claire Swyzen and Kurt Vanhoutte (eds.), Het statuut van de tekst in het postdramatische theater, Brussels, University Press Antwerp/Academic and Scientific Publishers, 2011, p. 125-135.

Voigts-Virchow, Eckart, "Mashup und intertextuelle Hermeneutik des Alltagslebens: Zu Präsenz und Performanz des digitalen Remix," MEDIENwissenschaft, 2015, no. 2, February 2015, p. 146-163, [Online] http://archiv.ub.uni-marburg.de/ep/0002/article/viewFile/3533/3406 [accessed 12 May 2015].

"WordHoard - The Texts: Provenance, Copyrights and Licenses," [Online] http:// wordhoard.northwestern.edu/userman/text-license.html [accessed 16 February 2018]. 


\section{NOTES}

1. Daniel Fischlin (ed.), OuterSpeares: Shakespeare, Intermedia, and the Limits of Adaptation, Toronto, University of Toronto Press, 2014, p. 5.

2. Marjorie Perloff, Unoriginal Genius. Poetry by Other Means in the New Century, Chicago, University of Chicago Press, 2010.

3. Jan Kott and Boleslaw Taborski, Shakespeare Our Contemporary, Garden City (N.Y.), Doubleday, 1966; Andrew Bennett, The Author, London, Routledge, "New Critical Idiom," 2005, p. 130.

4. "dat het dramatische model niet langer de evidente uitdrukking is van het postmoderne wereldbeeld." Pourveur paraphrased in Erwin Jans, "Drama na het drama? Een overzicht van postdramatische theaterteksten in Vlaanderen," in Claire Swyzen and Kurt Vanhoutte (eds.), Het statuut van de tekst in het postdramatische theater, Brussels, University Press Antwerp/ Academic and Scientific Publishers, 2011, p. 55. My translation from the Dutch.

5. John Drakakis, "Shakespeare in Quotations," in Susan Bassnett (ed.), Studying British Cultures. An Introduction, London/New York, Routledge, 1997, p. 170.

6. "Alles voor Heiner Müller hoort in het museum."

"Paul Pourveur over de Jaren 90," Toneelstof-website, 熙Online s=Paul_Pourveur_over_de_jaren_90 嚂accessed June 15, 2018医. My translation from the Dutch; Luk Van den Dries, “Heiner Müllers 'Hamletmachine' in een regie van Jan Decorte [1981]: postdramatisch theater avant la lettre," in Claire Swyzen and Kurt Vanhoutte (eds.), Het statuut van de tekst in het postdramatische theater, Brussels, University Press Antwerp/Academic and Scientific Publishers, 2011, p. 125-135.

"Theatre text" (from the Dutch "theatertekst") is a widely used term in the practice and criticism of theatre and performance in the Low Countries, at least since the 1990s and possibly the 1980s. It appeared in the German speaking world in Gerda Poschmann's Der nicht mehr dramatische Theatertext in 1997 (the term theatre text reduced to the more limited "play" in the publisher's translation of the title as "Plays without drama") and is increasingly adopted, among others, by Anglophone theatre and performance critics. In postdramatic theatre, the default theatre text is no longer the "dramatic text," but can alternately be a non-dramatic text taken from other literary or non-literary genres and from other media, can be generated in real time by human or non-human agents and does not necessarily take the form of a "play," with dialogue, characters, etc. "Theatre text" functions as a more general term for the text composed for, appearing, used or generated in a theatrical performance.

7. "wie of wat is er nu precies dood als Shakespeare dood is [...]?" (Erwin Jans, "Drama na het drama? Een overzicht van postdramatische theaterteksten in Vlaanderen," in Claire Swyzen and Kurt Vanhoutte (eds.), Het statuut van de tekst in het postdramatische theater, Brussels, University Press Antwerp/Academic and Scientific Publishers, 2011, p. 53). My translation from the Dutch.

8. Hans-Thies Lehmann, "From Logos to Landscape: Text in Contemporary Dramaturgy," Performance Research 2, no. 1, p. 56, [Online] http://dx.doi.org/10.1080/13528165.1997.10871532 [accessed 29 March 2019].

9. Jane Gallop distinguishes "literal," "theoretical" and "other authorial deaths" of authors. Jane Gallop, The Deaths of the Author: Reading and Writing in Time, Durham, Duke University Press, 2011.

10. From personal interviews by the author with Annie Dorsen: a Skype talk on June 22nd and a live talk in Brussels on August 18th, 2016.

11. Fischlin qtd. in Daniel Fischlin (ed.), OuterSpeares: Shakespeare, Intermedia, and the Limits of Adaptation, Toronto, University of Toronto Press, 2014, p. 27.

12. Andrew Bennett, The Author, London, Routledge, 2005, p. 95, 100-102; Sujata Iyengar, "Upcycling Shakespeare: Crafting Cultural Capital," in Daniel Fischlin (ed.), OuterSpeares: Shakespeare, Intermedia, and the Limits of Adaptation, Toronto, University of Toronto Press, 2014, p. 348. 
13. Andy Lavender, Hamlet in Pieces: Shakespeare Reworked: Peter Brook, Robert Lepage, Robert Wilson, London, Nick Hern Books, 2001, p. 14-15.

14. Thomas Leitch, "Twelve Fallacies in Contemporary Adaptation Theory," Criticism, vol. 45, no. 2, Spring 2003, p. 162, 165.

15. Andrew Bennett, The Author, London, Routledge, 2005, p. 29.

16. Andrew Epstein, "Found Poetry, 'Uncreative Writing,' and the Art of Appropriation," in Joe Bray, Alison Gibbons, and Brian McHale (eds.), The Routledge Companion to Experimental Literature, London, Routledge, 2012, p. 310; Daniel Fischlin, OuterSpeares: Shakespeare, Intermedia, and the Limits of Adaptation, Toronto, University of Toronto Press, 2014, p.35. Fischlin specifically mentions the "YouTube mashup."

17. Goldsmith qtd. in Marjorie Perloff, "Moving Information: On Kenneth Goldsmith's 'The Weather," Open Letter. A Canadian Journal of Writing and Theory 12, no. 7, 2005, p. 84, [Online] http://writing.upenn.edu/epc/authors/goldsmith/ [accessed 7 March 2018].

18. For the idea of "strong" and "weak" auctorial models, see Marysa Demoor, Ingo Berensmeyer, and Gert Buelens, "RAP - Authorship Studies | Faculty of Arts and Philosophy - Research Portal," [Online] http://research.flw.ugent.be/en/rap [accessed 4 March 2018];

Kenneth Goldsmith, Uncreative Writing: Managing Language in the Digital Age, New York, Columbia University Press, 2011.

19. Bertrand Gervais, "Is There a Text on This Screen? Reading in an Era of Hypertextuality," in Ray Siemens and Susan Schreibman (eds.), A Companion to Digital Literary Studies, Chichester, Wiley-Blackwell, 2013, p. 190. Gervais here specifies Lev Manovich's term "computer culture." Lev Manovich, The Language of New Media, Cambridge (Mass.), MIT Press, 2000, p. 43;

Eckart Voigts-Virchow, "Mashup und intertextuelle Hermeneutik des Alltagslebens: Zu Präsenz und Performanz des digitalen Remix," MEDIENwissenschaft 2015, no. 2, February 2015, p. 146,

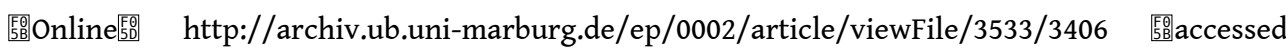
8 December 2015嚚.

20. Marjorie Perloff, “Moving Information: On Kenneth Goldsmith's 'The Weather."' Open Letter. A Canadian Journal of Writing and Theory 12, no. 7, 2005, p. 84, [Online] http://writing.upenn.edu/ epc/authors/goldsmith/ [accessed 7 March 2018]; Kenneth Goldsmith, Uncreative Writing: Managing Language in the Digital Age, New York, Columbia University Press, 2011, p. 1.

21. For the concept of "transcoding," see: Lev Manovich, The Language of New Media, Cambridge (Mass.), MIT Press, 2000, p. 47.

22. Kenneth Goldsmith, Uncreative Writing: Managing Language in the Digital Age, New York, Columbia University Press, 2011, p. 25-26.

23. Bernard Stiegler, "Memory," in W.J.T. Mitchell and Mark B.N. Hansen (eds.), Critical Terms for Media Studies, Chicago, University of Chicago Press, 2010, p. 70.

24. Lev Manovich, The Language of New Media, Cambridge (Mass.), MIT Press, 2000, p. 28; Bernard Stiegler, "Memory," in W.J.T. Mitchell and Mark B.N. Hansen (eds.), Critical Terms for Media Studies, Chicago, University of Chicago Press, 2010, p. 70.

25. Lev Manovich, The Language of New Media, Cambridge (Mass.), MIT Press, 2000, p. 20, 25-26.

26. Marjorie Perloff, Unoriginal Genius. Poetry by Other Means in the New Century, Chicago, University of Chicago Press, 2010, p. xi.

27. "un espace à dimensions multiples, où se marient et se contestent des écritures variées, dont aucune n'est originelle : le texte est un tissu de citations, issues des mille foyers de la culture » (Roland Barthes, "The Death of the Author" [1967] in Image Music Text, translation Stephen Heath, London, Fontana Press, 1977, p. 146).

28. Siobhan O'Flynn qtd. in Sujata Iyengar, “Upcycling Shakespeare: Crafting Cultural Capital," in Daniel Fischlin (ed.), OuterSpeares: Shakespeare, Intermedia, and the Limits of Adaptation, Toronto, University of Toronto Press, 2014, p. 349. 
29. "FB Theater," Kaaitheater, [Online] https://www.kaaitheater.be/en/agenda/fb-theater [accessed 7 March 2018].

30. Eric Paulos, "The Human Body as Multimedia," [Online] http://besser.tsoa.nyu.edu/impact/ f96/Reviews/epaulos/ [accessed 29 March 2019].

31. Mark Fortier, "Beyond Adaptation," in Daniel Fischlin (ed.), OuterSpeares: Shakespeare, Intermedia, and the Limits of Adaptation, Toronto, University of Toronto Press, 2014, p. 382.

32. Marjorie Perloff, Unoriginal Genius. Poetry by Other Means in the New Century, Chicago, University of Chicago Press, 2010, p. 17.

33. John Drakakis, "Shakespeare in Quotations," in Susan Bassnett (eds.), Studying British Cultures. An Introduction, London/New York, Routledge, 1997, p. 159; original emphasis;

Andrew Epstein, “Found Poetry, 'Uncreative Writing,' and the Art of Appropriation” in Joe Bray, Alison Gibbons, and Brian McHale (eds.), The Routledge Companion to Experimental Literature, London, Routledge, 2012, p. 315.

34. John Drakakis, "Shakespeare in Quotations," in Susan Bassnett (ed.), Studying British Cultures. An Introduction, London/New York, Routledge, 1997, p.163, 174; Sujata Iyengar, "Upcycling Shakespeare: Crafting Cultural Capital," in Daniel Fischlin (ed.), OuterSpeares: Shakespeare, Intermedia, and the Limits of Adaptation, Toronto, University of Toronto Press, 2014, p. 353, 357-363. As Iyengar indicates, the term "upcycling" was coined by William McDonough and Michael Braungart.

35. John Drakakis, "Shakespeare in Quotations," in Susan Bassnett (ed.), Studying British Cultures. An Introduction, London/New York, Routledge, 1997, p. 165.

36. Matt Cornish, "Kinetic Texts: From Performance to Poetry," Modern Drama 58, no. 3, Fall 2015, p. 305. [Online] https://doi.org/10.3138/md.0757 [accessed 29 March 2019].

37. Jerome Fletcher, "Introduction," Performance Research 18, no. 5 (October 1, 2013), p. 1. [Online] https://doi.org/10.1080/13528165.2013.867168 [accessed 29 March 2019].

38. Here, Shepherd and Wallis paraphrase W.B. Worthen. Shepherd, Simon, and Mick Wallis. Drama, Theatre, Performance, London, Routledge, "New Critical Idiom," 2004, p. 159.

39. Jerome Fletcher, "Introduction," Performance Research 18, no. 5 (October 1, 2013), p. 1. [Online] https://doi.org/10.1080/13528165.2013.867168 [accessed 29 March 2019].

40. Pascale Aebischer and Nigel Wheale qtd. in Daniel Fischlin, OuterSpeares, Toronto, University of Toronto Press, 2014, p. 5.

41. Aravind Enrique Adyanthaya, "Towards a Poor Techno-Theatre," Performance Research 18, no. 5, October 1, 2013, p. 81. [Online] https://doi.org/10.1080/13528165.2013.828926 [accessed 29 March 2019].

42. I discuss Edit Kaldor's Web of Trust in more detail, as well as Annie Dorsen's Hello Hi There in: Claire Swyzen, "Kaldor and Dorsen's 'Desktop Performances' and the (Live) Coauthorship Paradox," The Journal of American Drama and Theatre (JADT), vol. 30, no. 2, May 2018. [Online] http://jadtjournal.org/2018/05/29/kaldor-and-dorsens-desktop-performances/ [accessed 13 June 2018]. In this article, I also refer to the meaning of the blinking cursor.

43. Emma Cocker, "Live Notation: Reflections on a Kairotic Practice," Performance Research 18, no. 5, October 1, 2013, p. 71, [Online] https://doi.org/10.1080/13528165.2013.828930 [accessed 29 March 2019].

44. Emma Cocker, "Live Notation: Reflections on a Kairotic Practice," Performance Research 18, no. 5, October 1, 2013, p. 73, [Online] https://doi.org/10.1080/13528165.2013.828930 [accessed 29 March 2019].

45. Jerome Fletcher, "Introduction," Performance Research 18, no. 5, October 1, 2013, p.1-2.

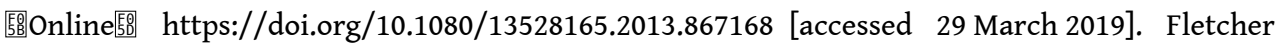
refers to N. Katherine Hayles's idea of the digital text as "a performance." Yet, such live composition is also imaginable with analogue text. 
46. Annie Dorsen, A Piece of Work, Brooklyn (N.Y.), Ugly Duckling Presse, "Emergency Playscripts 5," 2017, p. I.

47. David Berlinski, The Advent of the Algorithm: The 300-Year Journey from an Idea to the Computer, San Diego, Harcourt, 2001, p. xvi.

48. I discuss What You Will. Something by Shakespeare (2007) [Elk wat wils. Iets van Shakespeare] as a "database dramaturgy" in detail in Claire Swyzen, “The World as a List of Items': Database Dramaturgy in Low-Tech Theatre by Tim Etchells and De Tijd, Using Textual Data by Etchells, Handke and Shakespeare," Etum - E-Journal for Theatre and Media 2, no. 2 (December 19, 2015), p. 59-84, [Online] https://cris.vub.be/files/36172076/_ETUM_Swyzen.pdf [accessed 1 June 2018].

49. Orion Maxted, “Cybernetics vs. Decartes." Etcetera, [Online] https://e-tcetera.be/cyberneticsvs-decartes/ [accessed 18 December 2018].

50. I briefly discuss the idea of the "delegation of text production" in a review of Jisun Kim's Deep Present (2018) in the Belgian theatre journal Etcetera: Claire Swyzen, "Deep Present - Jisun Kim," Etcetera (blog) [Online] http://e-tcetera.be/deep-present-jisun-kim/ [accessed 13 June 2018] as well as in relation to Annie Dorsen's coauthorship with chatbots in her performance Hello $\mathrm{Hi}$ There (2010) in Claire Swyzen, “Kaldor and Dorsen's 'Desktop Performances' and the (Live) Coauthorship Paradox," The Journal of American Drama and Theatre (JADT), vol. 30, no. 2, May 2018. [Online] http://jadtjournal.org/2018/05/29/kaldor-and-dorsens-desktop-performances/ [accessed 13 June 2018].

51. Annie Dorsen, A Piece of Work, Brooklyn (N.Y.), Ugly Duckling Presse, "Emergency Playscripts 5," 2017, p. I.

52. Annie Dorsen, A Piece of Work, Brooklyn (N.Y.), Ugly Duckling Presse, "Emergency Playscripts 5," 2017, p. II. I have seen an unpublished video recording of the performance. Annie Dorsen, A Piece of Work - with Scott Shepherd, New York, Brooklyn Academy of Music, 2013.

53. Annie Dorsen, A Piece of Work, Brooklyn (N.Y.), Ugly Duckling Presse, "Emergency Playscripts 5," 2017, p. IV.

54. Constant, "Public Domain Day: The Death of the Authors," Constant vzw, [Online] http:// publicdomainday.constantvzw.org/ [accessed 4 March 2018].

55. Annie Dorsen, A Piece of Work, Brooklyn (N.Y.), Ugly Duckling Presse, "Emergency Playscripts 5," 2017, p. II; original emphasis. Bloom is quoted by Dorsen.

56. N. Katherine Hayles, How We Think: Digital Media and Contemporary Technogenesis, Chicago/ London, The University of Chicago Press, 2012, p. 176.

57. Thomas Leitch, "Twelve Fallacies in Contemporary Adaptation Theory," Criticism, vol. 45, no. 2, Spring 2003, p. 164.

58. Ioana B. Jucan, "Sys.Begin to Sys.Exit Software Performs A Piece of Work," TDR-the Drama Review-the Journal of Performance Studies 59, no.4, Winter 2015, p. 149-168. [Online] https:// doi.org/10.1162/DRAM_a_00502 [accessed 29 March 2018].

59. Dorsen, Annie, “A Piece of Work," [Online] http://www.anniedorsen.com/showproject.php? id=14 [accessed 14 June 2018]; Annie Dorsen, A Piece of Work - with Scott Shepherd, video recording, New York, Brooklyn Academy of Music, 2013. [Online; private video] https://vimeo.com/ 86944137 [accessed 4 March 2013].

60. Sarah Bay-Cheng, "UNSEEN Performance Criticism and Digital Recordings," Theater 46, no. 2 (2016), p. 77. [Online] https://doi.org/10.1215/01610775-3550508 [accessed 29 March 2019].

61. Sarah Bay-Cheng, "UNSEEN," Theater 46, no. 2 (2016): p. 80, [Online] https://doi.org/ 10.1215/01610775-3550508 [accessed 29 March 2019].

62. Sarah Bay-Cheng, "UNSEEN," Theater 46, no. 2 (2016): p. 83, [Online] https://doi.org/ 10.1215/01610775-3550508 [accessed 29 March 2019].

63. Steven Shaviro qtd. in Sarah Bay-Cheng, "UNSEEN," Theater 46, no. 2 (2016): p. 81, [Online] https://doi.org/10.1215/01610775-3550508 [accessed 29 March 2019]. 
64. Sarah Bay-Cheng, "UNSEEN," Theater 46, no. 2 (2016): p. 78, [Online] https://doi.org/ 10.1215/01610775-3550508 [accessed 29 March 2019].

65. "WordHoard - The Texts: Provenance, Copyrights and Licenses," [Online] http:// wordhoard.northwestern.edu/userman/text-license.html [accessed 16 February 2018].

66. Annie Dorsen, A Piece of Work, Brooklyn (N.Y.), Ugly Duckling Presse, "Emergency Playscripts 5," 2017, p. III-IV.

67. Annie Dorsen, A Piece of Work, Brooklyn (N.Y.), Ugly Duckling Presse, "Emergency Playscripts 5," 2017, p. IV.

68. Annie Dorsen, A Piece of Work, Brooklyn (N.Y.), Ugly Duckling Presse, "Emergency Playscripts 5," 2017, p. IV.

69. Annie Dorsen, A Piece of Work, Brooklyn (N.Y.), Ugly Duckling Presse, "Emergency Playscripts 5," 2017, p. IX.

70. Annie Dorsen, A Piece of Work, Brooklyn (N.Y.), Ugly Duckling Presse, "Emergency Playscripts 5," 2017, p. VII-VIII, XIII.

71. Espen Aarseth, Cybertext: Perspectives on Ergodic Literature, Baltimore (Md.), Johns Hopkins university press, 1997, p. 135.

72. Espen Aarseth, Cybertext: Perspectives on Ergodic Literature, Baltimore (Md.), Johns Hopkins university press, 1997, p. 55.

73. Annie Dorsen, A Piece of Work, Brooklyn (N.Y.), Ugly Duckling Presse, "Emergency Playscripts 5," 2017, p. VI.

74. Annie Dorsen, A Piece of Work, Brooklyn (N.Y.), Ugly Duckling Presse, "Emergency Playscripts 5," 2017, p. 1, 45, 73, 91, 129. In this paragraph I rely on the way the five algorithms are explained in Dorsen's book on the respective pages, but I refer only once to the book in this paragraph.

75. Johan Callens, "The Wooster Group's 'Hamlet', According to the True, Original Copies," Theatre Journal 61, no. 4, December 2009, p. 539.

76. Annie Dorsen, “Talk about 'A Piece of Work'. Group Self-Interview," TDR-the Drama Review 59, no. 4, Winter 2015, p. 134.

77. N. Katherine Hayles, How We Think: Digital Media and Contemporary Technogenesis, Chicago/ London, The University of Chicago Press, 2012, p. 202.

78. Lev Manovich, The Language of New Media, Cambridge (Mass.), MIT Press, 2000, p. 43, 230-231.

79. Lev Manovich, The Language of New Media, Cambridge (Mass.), MIT Press, 2000, p. 233.

80. Annie Dorsen, A Piece of Work, Brooklyn (N.Y.), Ugly Duckling Presse, "Emergency Playscripts 5," 2017, p. 83.

81. Ioana B. Jucan, "Sys.Begin to Sys.Exit Software Performs A Piece of Work," TDR-the Drama Review-the Journal of Performance Studies 59, no. 4, Winter 2015, p. 152, [Online] https://doi.org/ 10.1162/DRAM_a_00502 [accessed 29 March 2019].

82. Ioana B. Jucan, "Sys.Begin to Sys.Exit Software Performs A Piece of Work," TDR-the Drama Review-the Journal of Performance Studies 59, no. 4, Winter 2015, p. 157, [Online] https://doi.org/ 10.1162/DRAM_a_00502 [accessed 29 March 2019].

83. Thomas Cartelli, "Essentializing Shakespeare in the Shakespeare Aftermath: Dmitry Krymov's Midsummer Night's Dream (As You Like It), Matías Piñeiro's Viola, and Annie Dorsen's Piece of Work: A Machine-Made Hamlet," Shakespeare Quarterly 67, no. 4 (2016), p. 448, [Online] https:// doi.org/10.1353/shq.2016.0055 [accessed 29 March 2019].

84. N. Katherine Hayles, Writing Machines, Cambridge (Mass.), MIT press, 2002, p. 25.

85. Hans-Thies Lehmann, Postdramatic Theatre [1999], transl. Karen Jürs-Munby, London, Routledge, 2006, p. 17.

86. Ronald Geerts, "Tekst als object. Over de herwonnen autonomie van de dramatekst," in Claire Swyzen and Kurt Vanhoutte (eds.), Het statuut van de tekst in het postdramatische theater, Brussels, University Press Antwerp/ Academic and Scientific Publishers, 2011, p. 105-114. 
87. Annie Dorsen, “Talk about 'A Piece of Work'. Group Self-Interview," TDR-the Drama Review 59, no. 4, Winter 2015, p.136, [Online] https://doi.org/10.1162/DRAM_a_00501 [accessed 29 March 2019].

88. Claire Swyzen and Kurt Vanhoutte (eds.), Het statuut van de tekst in het postdramatische theater, Brussel, University Press Antwerp/ Academic and Scientific Publishers, 2011, p. 6. My translation from the Dutch.

89. Sue-Ellen Case qtd. in Philip Auslander, "Liveness, Mediatization, and Intermedial Performance," Degrés. Revue de synthèse à orientation sémiologique, no. 101, 2000, p. e5.

90. Aarseth, Espen, Cybertext: Perspectives on Ergodic Literature, Baltimore (Md.), Johns Hopkins university press, 1997, p. 141.

91. John Drakakis, "Shakespeare in Quotations," in Susan Bassnett (ed.), Studying British Cultures. An Introduction, London, New York, Routledge, 1997, p. 174.

92. Thomas Cartelli, “Essentializing Shakespeare in the Shakespeare Aftermath: Dmitry Krymov's Midsummer Night's Dream (As You Like It), Matías Piñeiro's Viola, and Annie Dorsen's Piece of Work: A Machine-Made Hamlet," Shakespeare Quarterly 67, no. 4 (2016), p. 433, [Online] https:// doi.org/10.1353/shq.2016.0055 [accessed 29 March 2019].

93. Lavender, Andy, Hamlet in Pieces: Shakespeare Reworked: Peter Brook, Robert Lepage, Robert Wilson, London, Nick Hern Books, 2001.

\section{ABSTRACTS}

Despite the dominance of the model of the romantic Genius in individual and educational writing practices in dramatic theater, postdramatic theater is gradually changing the status, materialities and functions of the text and of authorship. Authorship is dispersed and relocated, opened up to a range of authorial models "from Author to Data Processor." It is increasingly delegated to human and-still marginally-non-human coauthors. In a generalized "software culture" the theater auteur as Data Processor relies on three principles of "moving information": the transcodability (1) and citationality (2) of text data and the resulting "kinetic" effect (3) of theatre texts on stage. Though the digital has not, historically, been a condition for repurposing text material and for citational poetics, I will focus on New Yorker Annie Dorsen's "algorithmic" Hamlet appropriation A Piece of Work (2013), in which algorithms rewrite Shakespeare's canonical text and metaphorically submit it to a crash test.

\section{AUTHOR}

\section{CLAIRE SWYZEN}

Prior to conducting her doctoral research on "Text as Data in Postdramatic Mediaturgies" at the Vrije Universiteit Brussel, Claire Swyzen worked as a dramaturge for a Flemish theatre company and in practice-based research. She is an affiliated member of research groups CLIC (VUB) and Figura (UQAM). Among her publications are theatre texts, a volume on the status of the text in postdramatic theatre and an article in JADT. She taught dramaturgy and narratology to aspiring writers at Dutch and French-speaking drama departments in Belgium. 